Volume 7, Issue 4, 833 - 847.

ISSN: 2165-8714

http://www.eu-jer.com/

\title{
Human Resource Management Practices in Turkish Education System (Denizli Case)
}

\author{
Fatma Cobanoglu * \\ Pamukkale University, TURKEY
}

\author{
Gulsum Sertel \\ Pamukkale University, TURKEY
}

\author{
Sevda Seven Sarkaya \\ Pamukkale University, TURKEY
}

Received: July 17, 2018 - Revised: September 6, $2018 \cdot$ Accepted: September 10, 2018

\begin{abstract}
Human Resource Management (HRM) includes recruitment, training, development, motivation and evaluation of the staff who will achieve the goals of the organization and perform the necessary activities to be successful. The success of the organization depends on the effective use and management of human resources. Considering that The Ministry of Turkish National Education has the most crowded personnel and the potential of leading the future human resources, the HRM strategies of this organization becomes significant. In this study, it is aimed to investigate to the human resources management practices of the Ministry of Turkish National Education from the perspectives of teachers who are also the human resources of the system. In this research, holisticmultiple case study design was employed and the open-ended interview form which includes nine questions considering the functions of the HRM was utilized as the data collection tool. Research results showed that teachers know the duties and responsibilities which are declared in their job definition but they do not consider some of the significant professional efficiencies such as planning, assessment and evaluation. Moreover, the ministry does not make long-term plans in order to determine the required human resources, and also the functionality and subjectivity of the system is under discussion in terms of selection and appointment. What's more, the desired aims cannot be reached in terms of professional development. Teachers have the anxiety of performance evaluation based on accountability, and they emphasize fair and subjectivity in terms of payment, rewarding and discipline.
\end{abstract}

Keywords: Human resource management, Turkish education system, teachers.

To cite this article: Cobanoglu, F., Sertel, G., \& Seven Sarkaya, S. (2018). Human resource management practices in Turkish education system (Denizli case). European Journal of Educational Research, 7(4), 833-847. doi: 10.12973/eu-jer.7.4.833

\section{Introduction}

Today's organizations have to manage their human resources in the most effective way in order to take the advantage of competing under the rapid changes. Middlewood and Lumby (2009) avoided the term such as competitive and preferred more indefinite terms like effectiveness, success or optimal performance (p.5). They referred human resource management (HRM) as "the key to the provision of high-quality educational experiences" and that "educational organizations depend for their success on the quality, commitment and performance of people who work there (p.5)"

In the 1890s, when the industrial welfare work emerged slowly, people recognized that the principles of science could also be applied to the management of people. Wilkinson, Redman and Dundon (2017) stated that there is an alteration from direct systems of management (personal supervision, traditional paternalism, and simple piecework systems) to more technical systems of management and bureaucratic forms of employment (p.5). So in the late 1980s, the term HRM appeared as an alternative to personnel management. As Middlewood and Lumby (2009) indicated, the HRM is another but more strategic and dynamic interpretation of effective staff management in organizations. When Gary Becker from Chicago University got Nobel Prize in economics with his theory of "Human Capital", the term HRM became popular both in the world and in Turkey (Ulsever, 2005).

There has been an argument in the new interpretation of HRM whether it has only changed on paper or there has been a more sophisticated disguise (Wilkinson, et al., 2017). While this argument still continues, the important thing is that although it seems same to manage people and other sources in theory, it is quite different in practice in terms of skills, abilities, knowledge, personality, gender, the difference in experience, motivation, etc. (Bratton \& Gold, 1994). Moreover, all these variables should be managed well for the sake of organizational success.

Bratton and Gold (1994) defined HRM as "part of the management process that specializes in the management of people in work organizations" (p.5). It also includes hiring, training, developing, motivating and evaluating the personnel who

\footnotetext{
* Corresponding author:

Fatma Cobanoglu, Pamukkale University, Faculty of Education, Denizli, Turkey.

Email: fcobanoglu@pau.edu.tr
} 
would carry out the tasks required to reach the organizational goals. What the HRM aims at is to increase the productivity and the quality of the workplace by meeting the needs of employees; to take the advantage of competition; to guarantee the flexibility of work power. In this sense, HRM can meet the bureaucratic expectations of the organization. After all, HRM adopts the principles of competence, career, equality, assurance and objectivity (Akcakaya, 2008; Cengiz, 2010; Camlik, 2013; Ozdemir, 2014; Saylan, 2013 and Tan, 2015).

\section{HRM Practices in the Ministry of Turkish National Education}

The Turkish Educational System met the term of staff management between the years of 1960 and 1970, and the human resource management came into the scene with total quality management in 1990. Although HRM has rooted in the reform era in times of the Ottoman Empire, Human Resources Management Head Office was established under the Ministry of National Education (MoNE) in 2011 (25/8/2011, 652 number enactment).

Human Resources Management has an extensive structure consisting of sub-functions such as teachers' responsibilities and professional competency fields (job analysis), the quality and quantity of the human resource, selection and appointment, education and development, performance evaluation, fee, price and discipline management. The functions of Human Resources are important because it supports the organizational strategy through constructing, improving and sustaining a working power who is productive and proficient and have the required skills to reach the organizational goals (Decenzo, Robbins and Verhulst, 2017:30).

According to DeCenzo et al. (2017), job analysis is "the information and skills that the individuals need, and it gives information for the works in practice" (p.113) and it is considered as a starting point for HRM practices. Teaching is considered as a special expertise in National Turkish Educational System and is performed according to the main purposes and principles of national education. Training of preparation for teaching, world knowledge, special field education and pedagogical formation are serviced at the higher education institutions. On the other hand, teachers also gain the duties and responsibilities of teaching profession after they are assigned at schools through in-service education (1739 National Education Fundamental Law). Lately, in order to enhance the perception towards teaching profession, strengthen the statue of the teaching profession and increase the quality of the teachers, teachers' competencies have been defined under the dimensions of "occupational knowledge, occupational skill, attitude, and values". In this context, while occupational knowledge contains field knowledge, field education knowledge and the knowledge of regulations; occupational skill includes planning, constructing the learning environments, managing the teaching and learning process, assessment and evaluation. Moreover, the dimension of attitude and values includes moral and family values, approaching students, communication and collaboration, and professional development (Teacher Strategy Document, 2017-2023).

DeCenzo et al. (2017) stated HR planning is to provide an organization to reach an appropriate number of qualified employees at the right time and place. The MoNE determines the numbers of required teachers based on the weekly course loaded, teachers needed at the school, the number of classrooms and the number of students (Regulation for Permanent Staff of Administrators and Teachers Working on the MoNE Schools, 2016). Examining the regulations and practices of MoNE, there seem to be no clear criteria related to the qualifications of a teacher. What's more, teachers are selected according to their world knowledge, field knowledge and pedagogic knowledge (1739 National Education Fundamental Law, Item 45). Put differently, the MoNE takes into consideration the bachelor degree, public personnel selection examination, field knowledge examination and the interview in the selection of the teachers. Moreover, teachers are appointed as contractual personnel (the MoNE Regulation of Appointment and Translocation, 2015).

HRM gives the opportunity for the employees to develop and train themselves with its practices (Albrecht, Bakker, Gruman, Macey \& Saks, 2015). As to employ qualified teachers, to increase the personal and professional development of the teachers, and also to determine and eliminate the deficiencies of the teachers, MoNE organize induction and inservice education programs. The in-service education planning is published and spread every year, and it is conducted either mandatory or voluntary via distance or technology-based education, or face-to-face (Regulation of Training Inductive Teachers, 2017; Regulation of In-service Education, 1995).

Performance evaluation processes are strong tools for the participation and improvement of the employees if they are completed effectively. However, this process is occasionally managed in such a bad manner that it leads to disadvantages rather than advantages (DeCenzo et al., 2017). There are two basic purposes of teacher evaluation systems (OECD, 2009). One is to make the teacher evaluation for improvement which determines the strong and weak parts of the teaching occupation in order to improve the classroom practices of the teachers. In this way, the teachers' performance is evaluated as a component of school development plan. The other purpose of the teacher evaluation systems is to keep the teachers responsible for their performance and relate it with many outcomes for their professional career such as increase in salary, promotion, additional evaluation scores. Put differently, the accountability function of the teacher evaluation aims to encourage teachers to do their best at work. Based on the Teacher Strategy Document 2017-2023, the MoNE will change the teacher performance evaluation criteria into a 360 degree evaluation system. Nevertheless, it is still conducted as a pilot study in different regions. This evaluation includes a multiple evaluation systems fed from different sources considering the scores given by the parents, students, the teacher himself, other teachers and the administrators. On the other hand, the system aims at determining the 
success of the teachers via an examination conducted in every four years (2017-2023 Teacher Strategy Document, 2017).

In related to the wage system, DeCenzo et. al. (2017) indicated the top management aims to identify a charging system to prevent leaving the job and to motivate the employees, and moreover this system should be fair and equal for everyone. In Turkey, wage policies are determined based on the 657 Public Servants Law and include the social aids and services to the teachers. Similarly, the prizing and discipline system also take place in the 657 Public Servants Law. Nevertheless, a scheme is being prepared in the Teacher Strategy Document for career and prizing.

Apart from the regulations, examining the related literature, Benligiray (2009) stated that human resources management has not been attracted to 2000s in Turkey contrary to other countries because of the conditions in Turkey. Then, there seems to be an increase in the research such as master and Ph.D. dissertations. Tuncay (2015) ascertained that in the research, the USA HRM literature is basically considered. Although limited, there has been some research on "favoritism" which can be referred to the Turkey context. Although the MoNE is criticized not to put into the regulations into practice in terms of personnel management, it has been altering through HRM in an organizational context. Considering that the MoNE has the most crowded personnel and the potential of leading the future human resources, the HRM strategies of the MoNE becomes significant. However, except a few research (0ztay, 2006; Saylan, 2013), the practices have not been examined scientifically and holistically enough. In this sense, the current research aims to examine the views of teachers on the HRM practices performed by MoNE, and to identify "what the teachers think on" and "how they evaluate" the function of HRM.

\section{Methodology}

\section{Research Design}

The current study is designed as a case study as it is aimed to identify "what the teachers think on" and "how they evaluate" the human resources management practices of the Ministry of National Education (Yildirim and Simsek, 2013). HRM is handled as a case for the study. Each of the functions of HRM (the duties and responsibilities of teaching occupation, professional competence, the qualifications and quantity of the teachers, teacher selection and appointment, education and professional development, performance management, and "teacher salary, punishment and reward) can be considered as cases itself perceived independently so holistic-multiple case study design was used.

\section{Participants}

In this research, a total of 28 teachers working in state primary, secondary and high school in centre of Denizli according to the purposeful sampling. The school type and their teaching field were considered to provide the variation. In order to identify the common themes and their values among the views of the teachers who are working in such different types of schools (Yildirim and Simsek, 2013), maximum variation sampling method was used for the selection of the participants. Table 1 shows the demographics of the teachers.

Table 1. Demographics of the participants

\begin{tabular}{llc}
\hline \multirow{2}{*}{ School } & & $\mathrm{f}$ \\
& Elementary & 5 \\
& Secondary & 11 \\
& High school & 12 \\
\hline Gender & Female & 10 \\
& Male & 18 \\
\hline Educational Level & Bachelor degree & 26 \\
& Master degree & 2 \\
\hline Branch & Psychological Guidance and Counseling & 3 \\
& Pre-school /Classroom & 4 \\
& Turkish/English Language & 5 \\
& Mathematics/Science & 8 \\
& Social sciences & 3 \\
& Others (vocational, physical education, religion,...) & 5 \\
\hline Experience & $1-10$ year & 6 \\
& $11-20$ year & 7 \\
\hline
\end{tabular}




\section{Data Tools and Procedure}

Interview questions related to the literature on the HRM were prepared. Organized after the views of experts and results of the pilot study, the open-ended interview form includes nine questions considering the functions of the HRM. Some examples from the interview form as below: "Have you been educated related to the duties and responsibilities of the teaching occupation?"; "What are the professional efficiencies that a teacher should have?"; "What do you think about the practices of the MoNE in identifying the required qualifications and numbers of a teacher?"

As for the data analysis, a data set was prepared via transcription of the interviews records. The researcher and an expert having the qualitative research experience independently coded the data. Then, the codes were compared and sent to a third field expert. The last form of the code list was arranged under the sub-themes in terms of the main themes of each HRM function. In organizing the theme-code association, internal-homogeneity and externalheterogeneity were being into consideration. The dataset was re-examined in terms of themes and the last form of main theme-sub-theme-code association was constructed. The research was reported with direct quotations reflecting the related theme and codes. Moreover, for the validity and reliability of the research, the research design, study group, data collection tool and process, data analysis and results were explained in detail.

\section{Findings / Results}

According to the findings, the data were reported under the titles of seven main questions such as "the duties and responsibilities of teaching occupation", "professional competence", the qualifications and quantity of the teachers", "teacher selection and appointment", "education and professional development", "performance management", and "teacher salary, punishment and reward".

The duties and responsibilities of the teaching occupation

Participants' responses to whether they have taken any education on teaching occupation's duties and responsibilities were reported under the themes of pre-service and in-service, and are shown in Table 2.

Table 2. Training in regard to the duties and responsibilities of teachers

\begin{tabular}{lll}
\hline Theme & Code & $\mathrm{f}$ \\
\hline Pre-service & Bachelor degree & 21 \\
& Teacher Academy & 2 \\
\hline In-service & Induction period & 9 \\
& With experiences & 5 \\
& In-service training & 17 \\
& Books & 1 \\
\hline
\end{tabular}

Examining the views of the teachers, teachers have been informed about the duties and responsibilities of the teaching occupation both in pre-service and in-service education. A teacher stated "...we started to teach after we were educated on this issue. Moreover, we participated in in-service training" (T10). Some teachers indicated however, they have been informed via their experiences, "...teaching is learned through experience. You learn while teaching (T22)", and "I have taken pedagogical training at college and did not get any kind of other special education. I have learned my duties and responsibilities through years by my experiences (T1)".

\section{Professional competency}

Under the theme of professional competency that a teacher should have, sub-themes of professional knowledge, professional skill and attitudes and values were given in Table 3. 
Table 3. Teacher views on professional competency

\begin{tabular}{lllc}
\hline Main Theme & Sub-themes & Codes & f \\
\hline Professional & Professional knowledge & Professional knowledge & 20 \\
competency & (Field knowledge; Field education & Has taken pedagogical training & 3 \\
& knowledge; Regulations) & & \\
& Professional skill & Effective instruction & 13 \\
& (Planning, Preparing the environment, & Discipline & 4 \\
& managing the process, assessment and & Implementing the curriculum & 2 \\
& evaluation) & Objective assessment and evaluation & 1 \\
\cline { 2 - 4 } & Attitudes and Values & Attitude to students & 17 \\
& (National, Moral, Universal Values, Attitude to & Communication skill & 13 \\
& students, communication, cooperation, & About learning & 7 \\
& personal and professional development) & Positive attitude towards occupation & 6 \\
& & Being a role model & 4 \\
& & Scientific attitude & 5 \\
& & Being a leader & Interdisciplinary knowledge \\
\hline
\end{tabular}

Teachers mostly mentioned professional knowledge in regard to professional competencies that a teacher should have. A teacher stated that "... (a teacher) should be an expert in his/her field. S/he has to take pedagogical training... (T 4)", while another teacher indicated that "... (A teacher) should be qualified with knowledge of his/her field (T 10)". Apart from professional knowledge, teachers also underlined effective instruction related to professional skills. Apparently, teachers give importance to students' developmental properties and motivation under this sub-theme. These two state of the teachers exemplified the general views as "(a teacher) should perform methods and techniques appropriate for the students' ages (T 27)", and "... the teacher should know all the characteristics of his/her group age (T 8)". Furthermore, some teachers emphasized the management of the process and implementation of the curriculum stating that "...we are supposed to implement the curriculum at first (T 7)", and "... (A teacher) should manage the class. S/he can either make a joke or be angry in class (T 1)".

Nevertheless, teachers expressed their views mostly on teachers' attitudes and values. Particularly, the views on attitude towards students, communication and positive attitude towards the occupation are similar. some of the statements are such that "I think primarily commitment, self-sacrifice is important (T 13)"; "...has to be healthy, can transfers his/her energy to children (T 1)",; "...should love children and his/her job (T 1)"; "...when you enter the class, you are alone with the students. You have to put your problems aside so you can give all your attention to the students and be useful for them (T 14)"; "... (Teaching) is an occupation that should be performed with ties of affection (T 19)". In a similar way, teachers indicated their views on communication such that "Never mind how far a teacher is an expert in his/her field; if s/he cannot communicate well, s/he will be unsuccessful (T 17)", or "...should have an effective communication style, have the efficiency for reaching all ages of students (T 16)". Some of the teachers' statements are about being a role model as "Teachers should not only teach theoretical information of their fields but also be a role model (T 3)" and "...The child imitates you, copies almost everything from you. You are a model with your mimics, behaviors; with everything you have (T 8)". Apart from these, teachers emphasize the importance of personal and professional developments with the statements such as "...should be a teacher who develops him/herself in the field, is open to changes and innovations and updates him/herself (T 23)", or "...should have comprehensive knowledge on his/her field, follow the developments, and have the characteristics of investigating and questioning (T 28)".

\section{Qualifications and quantities of teachers}

Under the theme of attaining teachers by the MoNE in terms of their quality and quantity, sub-themes of teacher qualifications, teacher quantities, and suggestions were gathered. Table 4 displays the views of the teachers. 
Table 4. Teacher views on qualifications and quantities of teachers

\begin{tabular}{lllc}
\hline Main Theme & Sub-theme & Codes & \\
\hline Qualifications & Quantity & Adequate & 8 \\
and quantities & & Inadequate & 1 \\
\cline { 2 - 4 } & & Quality & Not consider the quality \\
& & Being graduated from Faculty of Education of & 13 \\
& & having a pedagogical training certificate & 8 \\
\cline { 2 - 4 } & Suggestions & Long-term planning & 21 \\
& & The quality of pre-service education should be & 14 \\
& & increased & 5 \\
& & Permanent staff & \\
\hline
\end{tabular}

Some teachers think that the number of the teachers are inadequate. T 11 stated, "The policies of the MoNE is not sufficient enough to determine the quality and quantity of the teachers. In some regions, there are many teachers and they cannot find a course to teach. However, some schools do not have teachers in some regions..." In other respect, participants indicated that the MoNE only considers the diploma or certificate of teaching to identify the qualifications such that "...The ministry considers the training at the faculty but I think this is not enough (T 6)". The suggestions of the teachers are the decrease in the number of faculties of education, long-term planning including a need analysis and implementing the permanent staff regulation. Moreover, the teachers suggest increasing the quality of pre-service education. Some statements about the suggestions are such as "...as the permanent staff system can be conducted well, needs can be determined more accurate (T 4); "...There are many graduates from the faculties. They cannot be appointed as teachers at the same time. A 10 or 15-year long-term planning should be made. The number of the faculties of education should be decreased, I think (T 5); "First of all, only the number of teachers needed by the ministry should be trained ( $T$ 27)"; "...The number of graduates is more than what the MoNE needs so the ministry and the university should be in coordination while determining the quota (T 28)"; "..I don't think that they make an effective planning, continuously a new faculty of education is being established (T 19)".

\section{Selection and appointment of the teachers}

The data was organized under the sub-themes of selection, appointment, and suggestions about the theme of selection and appointment of the teachers that the MoNE need. Table 5 displays the views of the teachers.

Table 5. The views of the teachers on the policies of teacher selection and appointment

\begin{tabular}{lllc}
\hline Theme & Sub-themes & Codes & $\mathrm{f}$ \\
\hline Selection $\begin{array}{l}\text { appointment } \\
\text { and }\end{array}$ & Selection & A fair selection & 30 \\
& & A selection exam & 11 \\
& & Inadequate & 3 \\
\cline { 2 - 4 } & \multirow{2}{*}{ Appointment } & Contractual appointment & 10 \\
& & Timing & 2 \\
& & Provisional appointment policies & 1 \\
\hline & \multirow{2}{*}{ Suggestions } & The selection system should be changed & 19 \\
& & There should be no change in fields & 1 \\
\hline
\end{tabular}

Teachers generally indicated the two-phased exam (oral and written) which is conducted as required by the regulations in terms of the selection of the teachers. T 5 stated, "Everyone graduated from the teacher training faculties can be a teacher, of course, if s/he can pass the exams". Nevertheless, teachers commented on the objectivity of the interviews and whether the selection is fair or not such as; "As the teacher selection policies depend on the interview today, it is unfair and intended to spoil system...Appointment policies are unfair, also (T 13); "Interview is at best subjective and open to interpretation. If a selection were subjective, then it would be suspicious. There should be objective, quantitative assessment (T 12)". Another teacher pointed out the fair appointment system stating, "I don't have enough information on questions and the interview. The important point here is to be objective. What the right thing is to appoint the deserved one (T 7)". As for the appointment policies of the ministry, the teacher mostly emphasized the contractual positions. While some teachers criticize the policy such as "... a teacher's being contractual. Who makes the contract and according to what? This may cause the teacher not to focus on his/her occupation enough (T 12)"; "I think contractual teaching arouse problems in training students. Human training is impossible with anxiety (T 13)", some others support indicating, "As we think our biggest aim is our students, there should not be students without teachers. In this sense, I think that contractual appointment is a right policy (T 7)". Examining the suggestions of the teachers, they think that the existing system should be changed. "I think it is wrong for a pre-service teacher to pass a written and an oral exam in terms of timing. It should be decided whether s/he could do teaching before the university (T 28)"; "it should be done in a fair and objective way for a qualified and sufficient number of teachers (T 28)". 
Training and Professional Development

Under the theme of training and developing in-service teachers, there are three sub-themes named negative, positive and suggestions. Table 6 displays the views of teachers about implementation.

Table 6. Teacher views on training and professional development of teachers

\begin{tabular}{llll}
\hline Main Theme & Sub-themes & Codes & f \\
\hline In-service & Negative views & Inadequate & 19 \\
training & & Reluctant teacher & 9 \\
& & Timing & 8 \\
& Not giving required importance & 6 \\
& Unproductive & 6 \\
& Unqualified/reluctant educator & 5 \\
& & Not participate in decisions & 3 \\
\cline { 2 - 3 } & Positive views & To identify the education need & 3 \\
& Various numbers of education & 3 \\
& Opportunity for the teacher & 2 \\
\cline { 2 - 3 } & Suggestions & Should increase the quality & 9 \\
& Collaboration with the university & 4 \\
& & Assessment and Evaluation & 2 \\
& & Voluntary participation & 2 \\
& Localization should increase & 1 \\
\hline
\end{tabular}

Many of the teachers have negative views on training and developing the inadequacies of the teachers. Some of the views are given below. "The MoNE published this year's education plan. When we examined it, we saw that there is not an in-service education plan to provide a professional development (T 2)"; "...When we examine the in-service education policy, there is training for the teachers but these trainings are perfunctory. The training does not suit their purpose (T 9). Although teachers indicated their negative views on in-service training, they also made self-criticism because of the reluctant teachers. "I don't think that in-service training is sufficient. They are not treated seriously enough. Maybe it is about us. There should be a perception of a requirement if there is a training (T 6)"; "There is actually good experiences for identifying the inadequacies but I think they are perfunctory. It is somehow because some friends perceive them as drudgery (T 13)". Apart from this, teachers underlined the timing of the training to increase the quality. "We as teachers also demand these (trainings). The problem is that the process is unproductive. The presenters are inadequate and boring, and timing is not suitable for the teachers (T 22); "It would be more productive if the in-service training is organized in seminar periods, midterm or summer sessions in order not to prevent the instruction (T 4)"; "I want to develop professionally, however, I cannot find enough time to participate in such training. As a woman, I cannot participate in such training (T 6)".

Teachers also commented on the educators who are other important components of in-service education: "...The ones who give the education should be the volunteer, qualified because teachers do not participate in these training voluntarily so they are not productive (T1)"; "...The ministry chose these educators without assessing their academic information. Is this the one who can give the education? How can s/he transfer? The ministry ignores these and just asks -can you take the charge? (T 8)".

Apart from all these negative views, one of the teachers said the ministry made need analysis for the educations: "...every year, an announcement about the in-service educations are made. We are asked in which area we need an education; we fulfill a form and send them ( $T$ 7)" Moreover, some teachers indicated that in-service training are opportunities for the teachers and there is much education that can benefit. The suggestions of the teachers about their observed problems are those in-service teachers might be more functional, teachers should not be forced to participate in these training, educations' outcomes should be evaluated and the cooperation with the academy should be increased. These are some statements of the teachers: "Generally, teachers are gathered in a place and somebody speaks. They make an exam and give a certificate but even they don't know whether the teachers have learned or not (T 11)", "...I think teachers need in-service education but they need a real one, more serious and practical (T14)"; "Some time the ministry collaborate with the academy, we have taken direct in-service education. I think they should be varied and continued (T 7)"; and "There should be experiences which suit the needs of today and functional; they should have taken our suggestions and practice them (T 20)".

\section{Performance evaluation}

Table 7 displays the teachers' views on the sub-themes of negative views and suggestions under the theme of performance evaluation carried out by the ministry 
Table 7. Teacher views on performance evaluation

\begin{tabular}{llll}
\hline Main Theme & Sub-themes & Codes & f \\
\hline Performance & Negative views & Wrong & 14 \\
evaluation & & The negative effect on the teacher & 9 \\
& & Inadequate & 6 \\
\cline { 2 - 4 } & Suggestions & Who should evaluate? & 15 \\
& & Objective criteria & 12 \\
& & Factors affecting success & 5 \\
& & Unnecessary & 2 \\
& & Career stages should be considered & 2 \\
\hline
\end{tabular}

Most of the teachers criticized the system planned and discussed lately rather than evaluated the current implementation of evaluation policy of the ministry. "Performance evaluation has been negotiated and got reactions. Performance criteria are very functional on paper. However, we have not trained the teacher in this way. We are expecting different criteria from the teacher we have trained (T 3)"; "This is not a system that develops the teacher performance. This is an implementation that damage the peace and communication between the teachers, parents, management ( $T 2)^{2}$ ". Apart from these criticisms, some teachers also added that this implementation might affect the teachers in a negative way: "Who will assess the performance? The parents? The student? According to what? Will it be objective? This is very troublesome. In case of being subjective, good teachers might become the target (T 4)"; "...It might be disturbing for a teacher to feel the necessity of recommending him/herself to the evaluators (T 7)". On the other hand, teachers have a disagreement about participating in the evaluation process. Some of the teachers indicated that all parts should be in the process, but some limited this in management, students or colleagues. Some of the teachers underlined the quality of the evaluator like T 27; "Evaluators should do their job if they have more sophisticated than the teachers".

Examining the suggestions about improving the implementation, the teachers have an agreement on objective evaluation criteria, while the other group stated that evaluation should be done considering the conditions affecting success. "It should be discriminated who is working and who is not. Performance evaluation should be more rationalist and more objective. The teacher cannot be evaluated with 100 questions. How can a parent evaluate the teacher? Can a parent who has never participated in school meetings evaluate the teacher? (T 3)". "...To educate a student in vocational high school is harder than for a student in science high school. That's why this situation should be regarded while evaluating, I think (T 10)"; "..our administrators evaluate us. I don't know according to which criteria are we evaluated (T 6)".

Salary, Rewarding and Discipline

Table 8 displays the teachers' views on the sub-themes of implementation and suggestions under the themes of payment, reward, and discipline.

Table 8. Teacher views on the salary, reward and discipline policies of MoNE

\begin{tabular}{lllc}
\hline Main Theme & Sub-themes & Codes & f \\
\hline Salary & Practice & Inadequate & 23 \\
& & Effect on professional performance & 6 \\
& & Adequate for country situations & 4 \\
& & 4 & 14 \\
\cline { 2 - 3 } & Suggestions & Should be revised & 17 \\
\hline Rewarding & Practice & Inadequate & 10 \\
& & Motivating & 5 \\
\cline { 2 - 3 } & Suggestions & Favoritism & 20 \\
& & Fair & 2 \\
& & Should not be material & 1 \\
& & Should be material & 1 \\
& & Education for the administrators & 1 \\
\hline Discipline & Practice & Not operating the discipline system & 6 \\
& & Being too tight & 6 \\
& & Adequate & 5 \\
& & Not deterrent & 2 \\
\cline { 2 - 3 } & Suggestions & System change specific for the & 8 \\
& & profession & 6 \\
& & It should be a self-control & 5 \\
& Should be same for everyone & 2 \\
\hline
\end{tabular}


Most of the teachers indicated that their salary is inadequate and charging policy should be revised while some others stated that their wages affect their performance and it is unfair. Some views of the teachers are as below; "The wages are unfortunately inadequate. We just make a living but cannot make any improving activities (T 10)"; "A teacher should feel comfortable economically (housing, childcare, bills, etc.), should not have financial problems, have a comfortable life ( $T$ 1)"; "I cannot get the education I would like to take because of the high prices. It is not only about the education; a teacher should also feel comfortable economically, psychologically and socially so s/he can give a qualified education. I cannot educate well unless I have not economic freedom, psychological well-being and good physical health (T 6)"; "Some of the teachers are really charged few but some others are high (T 28)". Another teacher rationalized the situation such as "If we evaluate the salary on the basis of my country, well, it is enough; however, it is not for the world. I just make a living. I cannot develop myself. It is not really enough (T 8)".

As for the reward policy of the ministry, most of the teachers think the system is insufficient while some others emphasized the effect of rewards on motivation, and the favoritism. In this sense, the teachers stated "...There should be a reward. It should be fair. The reward is surprisingly motivating (T1)" and "The importance of the reward cannot be ignored however it is critical when and according to which criteria it is given. Is it really a reward for success or qualification or is about politics and favoritism? (T20)". Accordingly, the teachers' most significant suggestion is the reward system should be fair. While one of the teachers stated "What is important is that what is the achievement of the students? It should be carefully examined and the reward should be given according to this. Subjective evaluations should be definitely removed (T27)", while another teacher brings a different perspective by saying "...we observe that school administrators are not charging as leaders. Some try to manage like a boss. So they do not know to acknowledge or rewarding. That is why maybe only the administrators can get an education on this issue. In this way, they can help the teachers in terms of human resources so the teachers are motivated (T19)".

Some of the teachers indicated that discipline system is not being implemented as T18 said, "It is not deterrent anymore. Like rewarding, punishment is not implemented also". Nevertheless, some teachers thought that the system is implemented so tight such as "You are in a definite frame as a state servant. You cannot behave ignoring laws and regulations. There should be a discipline but not for being late or not wearing a tie. However, if it continuously happens, perhaps there is a malicious intention so there should be a punishment (T11)". The most significant criticism of the teachers is that there is not any discipline model specific to the occupation, and teachers do not consider self-discipline. Some statements about this are, "People do not feel free under the disciplined approach which gives importance to appearance. A teacher who does not feel himself free is restricted. There should be an only discipline schedule but selfdiscipline should be regarded more (T16)", and "It should be more practical otherwise people believe that never mind what happens, nothing happens so they pay no attention (T8)". Another striking finding is that as in the reward system the teachers also emphasized fairness for the discipline system: "The punishment should be for who deserves like in the reward. There should be justice for both rewarding and punishment (T22)".

\section{Discussion and Conclusion}

It is clear that in the field of education, teachers have a powerful effect on student learning and school effectiveness. It is possible to paraphrase the statement of Bratton and Gold (1994) "Successful corporate leaders recognize that their competitive edge in today's marketplace is their people"(p.3) as "successful educational leaders should be aware of that the teachers have the effectiveness and success advantages for the national and international arena". It is because that reaching educational goals is closely related to the quality and quantity of the teachers who lead this process. Furthermore, if the teachers do not reflect each innovation in educational area to the learning environments, it is clear that no goal can be reached. This research examined the human resources management practices of the Ministry of Turkish National Education from the perspectives of teachers who are human resources and concluded that teachers have a pessimistic view about these practices in general.

As for the job analysis that is considered as a starting point for HRM practices, results showed that teachers learn the required duties and responsibilities in preservice and in-service education and they know the required duties and responsibilities. When it comes to required professional competencies they should have, despite of this result, they only give importance to the attitudes and values such as professional knowledge, approaching to students, communication and developing oneself while the especially focus on effective instruction and discipline in terms of "professional skill" (Teaching Occupation Basic Competencies) and they ignore the stages of planning, preparing the learning environments and assessment and evaluation which can determine the success of instruction process. In the study of Teacher Competencies by Turkish Education Association (2009), approximately one-third of the teachers indicated they do not believe in even the necessity of the lesson plans. Similarly, Sahin (2011) found that field knowledge and field education are the most important two of the values that a teacher should possess however assessment and evaluation is at last in this classification. Moreover, Arslan and Ozpinar (2008) concluded that inductive teachers feel inefficiency in the skills of using alternative assessment and evaluation techniques, and knowing professional rights and responsibilities even though they all take place in sourcebooks. Gelbal and Kelecioglu (2017) determined the teachers need education for preparing and using assessment techniques. 
Results on planning the necessary human resources in required quality and quantity showed that the Ministry does not make any need analysis and long-term planning and the Ministry does not give enough importance to the quality of teachers to be employed, and the diploma is seen to be enough to be employed even though it is not. It is obligatory for the success of the system that the MoNE should plan needed number and qualified of teachers. Nevertheless, in Turkey, there has been no planning for the need of teachers, moreover more teachers than needed have been trained in some fields. In the document of the 2010-2014 strategic plan of the MoNE, it is stated that supply and demand equilibrium cannot be provided enough, the education plans are short-term, and they often change. As a matter of fact, the Ministry indicates that the quota of the teacher training programs should be in accordance with the teacher requirement in its Teacher Strategy document (Strategy Document, 2017). Similarly, the MoNE has been carried out some attempts (the MoNE Teacher Profession Basic Competencies, 2006; 2017) to identify the teachers' competencies in order to train qualified teachers. Nonetheless, it is strictly criticized that although there are Faculties of Education, there are also some programs of certificate to train teachers in an unplanned way or surplus labor in other fields are appointed as teachers at this situations decrease the quality of the teaching profession (The TEDMEM Evaluation Report 2017: 71; Doganay et al., 2015; Yayla 2015; Azar 2011; Sisman 2009).

Current results revealed that teachers demand justice for the teacher selection and appointment policy of the ministry, especially for the oral exam, and also the current selection system should be revised. Ministry also emphasizes that selection of the teachers should be reorganized as multiple stages and with clear criteria. In this sense, the Ministry added there should a selection system in which alternative evaluation methods take place in and required basic competencies of the candidates can be evaluated (Strategy Document, 2017). Another issue about the selection of teachers is the preferred approach for the selection of teachers. As employing right people increase the productivity and profitability (DeCenzo et al., 2017: 30), selection of the teachers is an important human resources practice in terms of education system effectiveness. In Turkey, the teachers are selected via written and oral exams among the ones who have a diploma or certificate of teaching. In this sense, both university entrance examination and teacher selection examination are disputable in Turkey. Some research indicate that in Turkey, university entrance examination which assesses the cognitive domain fails to select students who have required qualifications for the faculty of education, and so teacher training programs need their own mechanisms to provide the opportunity of selecting their students (Sendag and Gedik 2015; Doganay et al. 2015; Sisman 2009; Gok, 2017; Yayla, 2015; Ozer and Alkan, 2017; Tekisik 1986). In addition to this, there are various approaches and models benefitted from for teacher training since the first years of Turkish Republic; however, teacher profession is not still at the desired level. According to Gunes (2016), some reasons for this situation are that some academics teach subjects that they think are important; enough important is not given to gain the required skills for teaching profession, transferring them to practice and teaching to students; and there are some courses which do not contribute to teachers and field teaching in the programs. Furthermore, the teachers do not think that the selection examination of the ministry is not appropriate to select a qualified teacher (Akdemir 2013; Sezgin and Duran, 2011; Memduhoglu and Kayan, 2017; Gundogdu, Cimen and Turan, 2008; Erdem and Soylu, 2013; Eraslan, 2004; Nartgun, 2011; Karatas and Gules, 2013; Guven, 2010).

Current research concluded about the professional function of the HRM that the teachers thought that the in-service training is inadequate, are not conducted in time and should be revised in terms of quality. Luthan et al. (2010) defined the psychological capital as "an individual's positive psychological state of development (p.2)", and concluded that shortterm training can provide an improvement in the on-the-job performance of the employees. Many of the research agree that a qualified in-service education is a tool for a qualified education as well (Training, P., \& Programmes In The E-, C., 2011; Theunissen and others, 1998; The European Commission, 2012; EURYDICE European Unit, 1995). Accordingly, the 2017-2023 Teacher Strategy Document of the Ministry also included the aim of continuous personal and professional development of the teachers (the MoNE, 2017). On the other hand as indicated in some research (Bayrakci, 2009; Tuncel and Cobanoglu, 2018) which also supports the findings of the current research, the most important problems facing in-service training activities in Turkey are a lack of professional staff, no collaborative partnerships between teachers, no provision for feedback and no systematic in-service training model.

Parallel with the views of teachers, inadequate need analysis might be the reason for these problems. Moeini (2008) indicated that in the most of the teacher training plans, need analysis is often ignored which not only causes waste of time, human resources, and money but also decrease the motivation and excitement of the individuals participating in the training. Instead of focusing on the pre-existing knowledge and beliefs of the teachers and their needs, the government-based in-service training concerns what teachers need to know and how they can be trained (Bayrakci, 2009). As Speck and Knipe (2001) indicated teachers displeased the professional development practices which are imposed on them from the top (cited in Bayrakci, 2009).

Considering the professional development theme, another research finding that can negatively affect the Ministry's HRM practices is that teachers are reluctant to get the in-service training. In TALIS research findings of OECD (2009) teachers in Turkey also perceive their own professional development need in low levels. Apart from the insufficient participation of teachers in the activities of professional development, they also do not feel any need for the development, and it is a critical obstacle for the professional development. In Turkey's teacher training process, teachers do not gain the skills of learning to learn, self-development and lifelong learning enough, and that is why there 
are some problems for teachers in progress and improvement in the profession (Gunes, 2016). However, as Beardwel and Thompson (2017) stated: "lifelong learning and development mean continuous adaptation" (p. 2017). When the individuals improve their knowledge and skills, they can adapt to the changes in their environment, moreover, they can have the strength of changing their environment.

Results related to performance evaluation indicated that teachers evaluated not the current implementation of performance evaluation but the planned new implementation negatively. Teachers referred this new implementation as wrong and inadequate, and they are anxious that apart from the development function of the performance evaluation, accountability function would come into prominence. As the concept of the workforce is quite different for the teaching profession in terms of effort and output, it is difficult to distinguish one teacher's effort from the other in the team (Lavy, 2007). As for the performance evaluation of the teachers, both development and accountability functions should be processed (Mercer, Barker \& Bird, 2010; OECD, 2009). According to the report of TEDMEM (2017), the designed practice about the aforementioned issue is criticized. Not surprisingly, teachers are inclined to share their deficiencies if they are evaluated for the sake of improvement, and as a consequence, this leads to effective decisions. However, when the evaluation affects their career or salary, this inclination changes (OECD, 2009).

In relation to the anxieties mentioned above teachers mostly handled the problem of objectivity, fairness, reliability, and validity of the evaluation criteria in terms of "objectivity". In the study by Koc and Soydan (2006) the participants also carry similar concerns. Moreover, the teachers especially concern about who would make the evaluation because the competencies of the competencies of the evaluators also determine the quality of the results (TED Teacher Competencies Report, 2009). Some researchers in education field also share the teachers' anxiety about who will participate in the evaluation process. They think that competency in performance evaluation, accountability, and feeling responsible for the outcomes of the evaluation are important factors. Contrary to the system, direct scoring of evaluation process might have unfair results (TEDMEM Evaluation Report, 2017).

The results for the functionality of the payment showed that the teachers thought their salary is not enough and the economic problems they have affect their performance and personal development negatively. Indeed, the annual amount of the teachers' wages in Turkey are below the average of OECD member countries (OECD, 2009; 2017). Some research indicates that low income is one of the important problems of the teachers in Turkey (Guven 2003; Demir and Ari 2013; Tekisik 1986; Goker and Gunduz 2017), and the teachers are negatively affected because of the extra hours they have to take (Guven, 2010). Additionally, increased income might motivate the teachers (Kingdon \& Teal, 2007) and encourage them to continue the profession (Imazeki, 2005). Ali (2009) analyzed in his study PISA 2000, 2003 and 2006 survey data of the students' scores among the OECD member countries and found out that teachers' wages have a positive effect on students' performance.

As for the rewarding function, the research concluded that the teachers think that the rewarding system is not carried out effectively but it motivates them. However, they demand fairness for the system also. Similar studies emphasized the inefficiency of the rewarding system and there should be a system based on objective criteria (Yildirim, 2008; Silah, 2001; Celebi et al., 2015; Ekinci, 2008). Nevertheless, considering the performance, rewarding is one of the motivation sources. Reward affect the performance of the employees and their future behaviors (Pekdemir et al, 2014), and employees mostly prefer material rewards (Tozlu, 2015). Similarly, teachers think about the discipline system that it is not carried out, implemented too tight and there should be a new discipline model. Furthermore, they criticize that the discipline regulations are all the same for all state servants in Turkey and administrators should employ the discipline rules consistently and objectively. HRM approach includes focusing on the desired behaviors of the employees, not the undesired ones. So the employees had a better intention to obey the organizational rules in their free will. Otherwise, the creativity disappears and sometime after there occurs the senses of ailment or hatred (Saylan, 2013). Employees normally take the control of their discipline by behaving as expected. At this point, the important thing is to determine the discipline rules and sanctions for the duties and responsibilities of the teachers.

\section{Implications}

Although the teachers indicated that they had the training of their duties and responsibilities in their pre-service and in-service education processes, they did not mention about planning, assessment and evaluation for the professional competencies which are very important issues for the quality of an instruction. This might refers inadequate information about the aforementioned duties and responsibilities. In this sense, it should be guaranteed that the teachers have enough information about job analysis which bases the other functions of HRM such as professional development, performance management, rewarding and discipline. The Ministry might identify the needs on this issues by organizing an extensive pre-service and in-service education for the required professional duties and responsibilities.

The Ministry should also make a need analysis for the selection and appointment of the needed teachers, and moreover it should consistently implement this plan and consider subjectivity and competence. It is important that the Ministry should plan in-service education based on need analysis and implement this education with considering that the teachers are the learners also. Besides, the evaluation process of the teachers' performances should be carried out as a 
supportive way, rather than focusing on only accountability. As for the payment, rewarding and discipline function the feeling of fairness might increase if a clear set of rules are determined to restore the trust of teachers who are concerning about the objectivity.

Considering the results in a holistic way, it would be effective on solving the observed problems to make a collaboration with related institutions (as teacher training institutions) and persons (teachers, administrators, etc.) and to make scientific research on the functions of HRM. Such examples of attempts can be given on this issue as to make a need analysis to identify the professional development needs or need qualified teachers; to implement the plans; to collect data about the payment policies in educational institutions of different societies to make comparisons. Moreover, it would be useful to function HRM system, if the school administrators get an education about the possible effects of teacher training, teacher development, performance evaluation, rewarding and discipline on the teacher.

\section{Limitations}

This research examined the views of teachers on the policies and practices of Ministry of Turkish National Education HRM functions through the interviews. School administrators and Ministry bureaucrats who are the other stakeholders of the HRM practices are out of the scope of the research. In this sense, a more comprehensive outline can be reached if the issue is examined from different perspectives with mixed data collection methods.

\section{Acknowledgements}

This study was presented as two different oral presentations at 27th International Conference on Educational Sciences in Antalya.

\section{References}

Akcakaya, M. (2008). Insan kaynaklari planlamasinin bir araci olarak norm kadro uygulamasi [Human Resources Planning as a Tool of Norm Staff Application] (Unpublished Doktoral Dissertation). Gazi University, Ankara, Turkey.

Akdemir, A. S. (2013). Turkiye'de ogretmen yetistirme programlarinin tarihcesi ve sorunlari [History of teacher training programs and their problems in Turkey], Turkish Studies, 8(12), 15-28.

Albrecht, S. L, Bakker, A. B., Gruman, J. A., Macey, W. H., \& Saks, A. M. (2015) Employee engagement, human resource management practices and competitive advantage: An integrated approach, Journal of Organizational Effectiveness: People and Performance, 2 (1), 7-35. https://doi.org/10.1108/JOEPP-08-2014-0042.

Ali, A. A. (2009). The impact of teacher wages on the performance of students: evidence from PISA, MPRA Paper No. 18252, retreived from https://mpra.ub.uni-muenchen.de/18252/1/MPRA_paper_18252.pdf.

Arslan, S., \& Ozpınar, I. (2008). Ogretmen nitelikleri: ilkogretim programlarinin beklentileri ve egitim fakultelerinin kazandirdiklari [Teachers qualifications: comparison between primary school curriculum expectations and teachers acquisitions in education faculties]. Necatibey Faculty of Education Electronic Journal of Science and Mathematics Education, 2(1), 38-63.

Azar, A. (2011). Turkiye'deki ogretmen egitimi uzerine bir soylem: nitelik mi, nicelik mi? [Quality or quantity: A Statement for teacher training in Turkey]. Journal of Higher Education and Science, 1(1), 36-38.

Bayrakci, M. (2009). In-Service Teacher Raining in Japan and Turkey: a comparative analysis of institutions and practices, Australian Journal of Teacher Education, 34(1), 10-22.

Beardwell, J., \& Thompson, A. (2017). Human resource management (Eighth edition), Pearson Education Limited, United Kingdom.

Benligiray, S. (2009). Turkiye'de insan kaynaklari yonetimi alaninda yapilan lisansustu tezler ve bu tezlerde incelenen temalarin analizi: 1983-2008 donemi [The theme analysis of the postgraduate theses written on human resource management in Turkey: 1983-2008 period]. Eskisehir Osmangazi University Journal of Economics and Administrative Sciences, 4(1), 167-197.

Bratton, J., \& Gold, J. (1994). Human resource management. London: The Macmillan Press.

Cengiz, E. (2010). Insan kaynaklari yonetiminde ogretmenlerin orgutlenme hakki [The organizing right of the teachers in human resources management] (Unpublished Master's Thesis). Beykent University, Istanbul, Turkey.

Camlik, M. (2013). Insan kaynaklari yonetimi uygulamalarinin calisanlarin mental sagligi uzerindeki etkisi: Mersin ve Adana illerindeki kamu ve vakif universitelerinde bir uygulama [The effect of human resources management practices on the mental health of the employees: An application in public and private universities in the provinces of Mersin and Adana] (Unpublished Master's Thesis). Mersin University, Mersin, Turkey. 
Celebi, N., Vuranok, T. T., \& Hasekioglu Turgut I. (2015). Ilk ve ortaokullarda ogretmenlerin odul sistemine iliskin gorusleri [The perceptions of primary and secondary school teachers on reward system], Mehmet Akif Ersoy University Journal of Faculty of Education, 34, 75 -104.

DeCenzo, D. A., Robbins, S. P. Verhulst, S. L. (2017). Insan kaynaklari yönetiminin temelleri [Fundamentals of human resource management], Ankara: Nobel Academic Publishing.

Demir, M. K., \& Ari, E. (2013). Ogretmen sorunlari-Canakkale ili ornegi [Teacher problems-Canakkale Case]. Ondokuz Mayis University Journal of Faculty of Education, 32(1), 107-126.

Doganay, A., Akbulut Tas, M., Yesilpinar, M., Yolcu, E., Turhan Turkkan, B., Sari, M., Karakus, M., Aybek, B., Sadik, F., \& Akbulut, T. (2015). Hizmet oncesi ogretmen egitiminde model arayisi [Search for a New Model in Pre-Service Teacher Education]. International Journal of Curriculum and Instructional Studies, 5(9), 1-21.

Ekinci, F. (2008). Kamu personel yonetiminden insan kaynaklari uygulamasina gecisin calisanlarin verimliligine etkisi [The effect of transition from public personnel management to human resources application on employee productivity]. Journal of Finance, 155, 155-185.

Eraslan, L. (2004). Ogretmenlik meslegine giriste kamu personeli secme sinavi (KPSS) yonteminin degerlendirilmesi [Evaluation of Public Personnel Selection Examination (KPSS) method in the field of teaching profession]. International Journal of Human Sciences, 1-31. Retrieved from http://www.jhumansciences.com/ojs/index.php/ IJHS/article/view/167

Erdem, E., \& Soylu, Y. (2013). Ogretmen adaylarinin kpss ve alan sinavina iliskin gorusleri [Teachers' views on KPSS and field examination]. Cankırı Karatekin University Journal of Institute of Social Sciences, 4(1), 223-236.

EURYDICE (1995). In-service training of teachers in the European Union and the EFTA/EEA countries. European Unit, Belgium.

Gelbal, S., \& Kelecioglu, H. (2007). Ogretmenlerin olcme ve degerlendirme yontemleri hakkindaki yeterlik algilari ve karsilastiklari sorunlar [Teachers' proficiency perceptions of about the measurement and evaluation techniques and the problems they confront]. Hacettepe University Journal of Education, 33, 135-145.

Gok, E. (2017). Defining quality in teacher education: Initial lessons from Turkish public higher education institutions. Educational Administration: Theory and Practice, 23(4), 623-673. doi:10.14527/kuey.2017.020

Goker, S. D., \& Gunduz, Y. (2017). Dunya olceginde ogretmenlerin sayginlik statusu ve ozluk haklari [Teacher status and their employee personal rights across the World], Journal of National Education, 213, 177-196.

Gundogdu, K., Cimen N., \& Turan S. (2008). Ogretmen adaylarinin kamu personeli secme sinavina (KPSS) iliskin gorusleri [Novice teachers' views on the selection of public personnel examination (KPSS)], Ahi Evran University Journal of Kirsehir Faculty of Education, 9 (2), (35-43).

Gunes, F. (2016). Ogretmen yetistirme yaklasim ve modelleri [Approaches and models in teacher education], Ahi Evran University Journal of Kirsehir Faculty of Education, 17(3), 413-435.

Guven, D. (2010). Profesyonel bir meslek olarak Turkiye'de ogretmenlik [Teaching as a profession: the case of Turkey], Bogazici University Journal of Education, 27 (2), 13-21.

Guven, I. (2003). 1940'dan gunumuze ogretmenlerin ekonomik sorunlarinin tarihsel analizi [Historical analysis of the economic problems of teachers since 1940], Journal of National Education, 160.

Imazeki, J. (2005). Teacher salaries and teacher attrition, Economics of Education Review, 24, 431-449

Karatas, S., \& Gules H. (2013). Evaluation of the selection exam for civil servants (KPSS) from pre-service teachers' perspectives. Journal of Theoretical Educational Science, 6(1), 102-119.

Kingdon, G. G., \& Teal, F. (2007). Does performance related pay for teachers improve student performance? Some evidence from India, Economics of Education Review, 26, 473-486.

Koc, M. (2006). Kamu personel rejimi icerisinde devlet memurlarinin basarisinin degerlendirilmesi ve basariya dayali ucretin devlet memurlarina uygulanabilirligi [Evaluating the success of civil servants in the public personnel regime and the applicability of fee based on success to the civil servants] (Unpublished Master's Thesis), Gazi University, Ankara, Turkey.

Lavy, V. (2007). Using performance-based pay to improve the quality of teachers, The Future of Children, Excellence in the Classroom, 17(1), 87-109.

Luthans, F., Avey, J., B., Avolio, B. J., \& Peterson, S. (2010). The development and resulting performance impact of positive psychological capital, Human Resource Development Quarterly, 21(1), 41-67. doi 10.1002/hrdq.20034 
Memduhoglu, H., \& Kayan, M . (2017). Ogretmen secme ve atama uygulamasi olarak kamu personeli secme sinavina (KPSS) iliskin ogretmen adaylarinin algilari [The perceptions of novice teachers in related to public staff selection examination (KPSS) as teacher selection and assignment practice]. Yuzuncu Yil University journal of Faculty of Education, 14 (1), 1259-1288.

Mercer, J., Barker B., \& Bird R. (2010). Human Resource Management in Education, New York: Routledge.

Middlewood D., \& Lumby J. (2009). Human resource management in schools and colleges. London: SAGE Publication Ltd.

Ministry of National Education [MoNE], (2017). Teacher Strategy Document 2017-2023, Ankara: Turkey.

Moeini, H. (2008). Identifying needs: A missing part in teacher training programs, International Journal Of Media, Technology And Lifelong Learning, 4 (1), 1-12.

Nartgun, S (2011). Employment of faculty of education students: public personnel selection examination (PPSE) International Journal of Business and Social Science, 2(21), 101-111.

OECD (2009). Teacher evaluation a conceptual framework and examples of country practices.

OECD (2017). Education at a Glance 2017: OECD Indicators, OECD Publishing, Paris. http://dx.doi.org/10.1787/eag2017-en

Ozdemir, M. (2014). Egitim orgutlerinde insan kaynaklari yonetimi, kuram uygulama teknik [Human resources management in educational institutions, theory application technical]. Ankara: Ani Yayincilik.

Ozer B., \& Alkan S. (2017). Comparison of Teacher Training Programmes of EU and Turkey and A Model Suggestion for Turkey, Journal of Interdisciplinary Educational Research, 1(1); 62-95.

Oztay F. E. (2006). Egitim orgutlerinde insan kaynaklari yonetimi ile olusturulmus kurum kulturunun ogretmen motivasyonuna etkisi [The effect of organizational culture on teacher motivation created by human resources management in educational organizations]. (Unpublished Master's Thesis), Yeditepe University, Istanbul, Turkey.

Pekdemir, I., Kocoglu, M., \& Gurkan, G. C. (2014). Ozerklik ve odullendirme algilarinin calisan performansi uzerindeki etkisinde calisanin inovasyona yonelik davranisinin aracilik rolune yonelik bir arastirma [An investigation on the mediating role of employee innovation behavior on the relationship between autonomy and reward]. Istanbul University Journal of the School of Business, 43(2), 332-350.

Saylan N. (2013). Ozel ilkogretim ve ortaogretim okullarinda insan kaynaklari yonetimi islevlerinin gerceklesme derecesi [The degree of realization of human resources management functions in private primary and secondary schools] (Unpublished Master's Thesis). Hacettepe University, Ankara, Turkey.

Sezgin F., \& Duran E. (2011). Kamu Personeli Secme Sinavi'nin (KPSS) Ogretmen adaylarinin akademik ve sosyal yasantilarina yansimalari [The reflections of the public personnel selection examination on teacher candidates' academic and social lives], Turkish Journal of Social Research, 15(3), 9-22.

Silah M. (2001) Egitim orgutlerinde hizmetin niteligini arttirmak icin personelin odullendirilmesi [Being rewarded for quality of servis in education organizations], Cumhuriyet University Journal of Economics and Administrative Sciences, 2(1), 95-109.

Soydan T. (2012). Egitim alaninda performans degerlendirme sisteminin gecerligi uzerine yonetici ve ogretmen goruslerine dayali bir arastirma [A research based on the views of managers and teachers about the effectiveness of the performance evaluation system in the field of education], Ege Education Journal, 13(1): 1-25.

Sahin, A. (2011). Ogretmen algilarina gore etkili ogretmen davranislari [Effective teacher's attitudes according to teacher's perceptions]. Ahi Evran University Journal of Kirsehir Faculty of Education, 12(1), 240-259.

Sendag, S., \& Gedik N. (2015). Yuksekogretim donusumunun esiginde Turkiye'de ogretmen yetistirme sorunlari: bir model onerisi [Teacher training problems of Turkey on the threshold of higher education transformation and a support model]. Educational Technology Theory and Practice, 5(1), 72-91.

Sisman, M. (2009). Teacher's competencies: a modern discourse and the rhetoric. Inonu University Journal of the Faculty of Education, 10(3), 63-82.

Tan, S. (2015). Ortaogretim kurumlarinda insan kaynaklari yonetimi ve bir uygulama [Human resources management in secondary schools and an implementation] (Unpublished Master's Thesis), Istanbul Arel University, Istanbul, Turkey.

TEDMEM, (2017). 2017 Education Evaluation Report, Ankara: TED.

Tekisik H. H. (1986). Turkiye'de Ogretmenlik Meslegi ve Sorunlari [Teacher profession in Turkey and its problems], Journal of Contemporary Education, 11(116), 1-9. 
Tozlu A. (2015). Kamu gorevlilerinin performansa dayali odul tercihleri [Public employees' performance-based reward preferences], Journal of Finance, 168, 249-272.

Tuncay M. (2015). Turkiye ve ABD insan kaynaklari yonetimi yazinlarinin ele aldiklari konular acisindan karsilastirilmasi: Bir icerik analizi (2004 - 2015) [The comparison of Turkey and the USA human resource management literature in terms of topics: a content analysis] (Unpublished Master's Thesis). Cankaya University, Ankara, Turkey.

Tuncel, Z. A., \& Cobanoglu, F. (2018). In-service teacher training: problems of the teachers as learners. International Journal of Instruction, 11(4), 159-174.

Turk Egitim Dernegi [Turkish Education Association] (2009). Ogretmen yeterlikleri raporu [Teacher Competencies Report], Ankara: Turk Egitim Dernegi Yayini.

The European Commission (2012). Supporting the teaching professions for better learning outcomes. Commission staff working document. Strasbourg, SWD(2012).

Theunissen, M., \& Veenman, S. (1998). Interorganisational Networks in the Domain of In-Service Teacher Training. Reports, Catholic Univ., Nijmegen (Netherlands).

Training, P., \& Programmes In The E-, C. (2011). Teachers as lifelong learners: case studies of innovative in-service teacher training programmes in the E-9 countries.

Ulsever, C. (2005). 21. yuzyilda insan yonetimi [21st century human management], Istanbul: Alfa Yayincilik.

Wilkinson A., Redman T., \& Dundon T. (2017). References contemporary human resource management text and cases (Fifth Ed.). United Kingdom: Pearson Education Limited.

Yayla, A. (2015). Nitelikli ogretmenlerin yetistirilme surecinde yeni arayislar: sorunlar ve cozum onerileri [New searches in the process of training qualified teachers: problems and solutions], TYB Academy Journal of Language, Literature and Social Sciences, 5(13), 109-122.

Yildirim M. C. (2008). Ilkogretim okulu ogretmen ve yoneticilerinin ogretmenlerin odullendirilmesine iliskin gorusleri [Primary school teachers' and administrators' views about rewarding teachers], Educational Administration: Theory and Practice, 56, 663-690.

Yildirim, A., \& Simsek, H. (2013). Sosyal bilimlerde nitel arastirma yontemleri [Qualitative research methods in social sciences]. Ankara: Seckin Yayincilik. 